\title{
Short-term treatment for acute myelogenous leukaemia
}

\author{
R BELL, A Z S ROHATINER, M L SLEVIN, J M FORD, H S DHALIWAL, G HENRY, \\ B G BIRKHEAD, J A L AMESS, J S MALPAS, T A LISTER
}

\begin{abstract}
Short-term treatment with doxorubicin, cytarabine, and 6-thioguanine was given to 91 consecutive adults with acute myelogenous leukaemia. Fifty patients received high doses (regimen I) and 41 very high doses (regimen II). Where possible, six treatment cycles were given (total dose of doxorubicin $450 \mathrm{mg} / \mathrm{m}^{2}$ ) regardless of the number of cycles required to achieve complete remission. No additional treatment was given. The remission rate was significantly higher with regimen I than with regimen II (34/50 compared with $15 / 41, p<0.01)$, the latter, more intensive regimen being associated with a greater incidence of fatal infection (13/41 compared with $5 / 50$, $p<0.01)$. Duration of remission was, however, significantly longer with regimen II $(p<0.05)$; the median has not yet been reached after a minimum follow-up of two years.

Intensive short-term treatment is a feasible strategy for
\end{abstract} the treatment of acute myelogenous leukaemia.

St Bartholomew's Hospital, London EC1A 7BE

$R$ BELL, FRACP, ICRF research fellow and honorary senior registrar (present address: Section of Medical Oncology, University Hospital, Boston, Massachusetts 02118, USA)

A Z S ROHATINER, MRCP, ICRF research fellow and honorary senior registrar

$M$ L SLEVIN, MRCP, ICRF research fellow and honorary senior registrar J M FORD, MD, MRCP, ICRF research fellow and honorary senior registrar (present address: Princess Margaret Hospital, Toronto, Ontario, Canada)

$\mathrm{H} S \mathrm{~S}$ DHALIWAL, MRCP, ICRF research fellow and honorary senior registrar

G HENRY, BSC, data officer

J A L AMESS, MRCP, FRCPATH, consultant haematologist

J S MALPAS, DPHIL, FRCP, director, Imperial Cancer Research Fund, department of oncology

T A LISTER, MD, MRCP, deputy director, Imperial Cancer Research Fund, department of oncology

Research Centre for the Mathematical Modelling of Clinical Trials, University of Warwick

B G BIRKHEAD, MSC, FSS, research fellow

\section{Introduction}

The first formal attempts at curative treatment for acute myelogenous leukaemia at St Bartholomew's Hospital, London, comprised relatively mild (by today's standards) remission induction therapy followed by monthly maintenance chemotherapy, with or without immunotherapy. ${ }^{12}$ Complete remission was achieved in about $40 \%$ of patients; however, the median duration of remission was short and there were few long-term survivors. ${ }^{3}$ Intensifying the initial treatment with essentially the same maintenance regimen did not improve the complete remission rate, because of failure to prevent or control infection, nor did it prolong the median duration of remission. Nevertheless, the overall shape of the disease-free survival curve was significantly different from that seen previously; one-fifth of patients continued in first remission after three years and none subsequently relapsed. ${ }^{4}$ This improvement suggested that intensification of the initial treatment was the major factor in prolonging long-term survival.

Reports that complete remission could be achieved in most patients with combinations of an anthracycline with cytarabine and 6-thioguanine ${ }^{5}{ }^{6}$ led us to use them in a high-dose schedule of six cycles over about five months. On the basis of widely expressed doubts about maintenance chemotherapy and the obvious advantage to both patient and physician of reducing the duration of treatment, no further treatment before relapse was given, unless the patient was under the age of 40 and had an HLA-identical sibling; allogeneic bone marrow transplantation was then performed. The results of this approach are reported here.

\section{Patients and methods}

Study group-Ninety-one consecutive, previously untreated adults with acute myelogenous leukaemia were referred to the ICRF department of medical oncology, St Bartholomew's Hospital, between April 1978 and June 1980 and formed the study group. Fifty received intensive (regimen I) and 41 very intensive (regimen II) treatment (tables I-III). During the study, erythroleukaemia developed in one additional patient with longstanding refractory anaemia and an excess of blasts; he was not treated; there were no other exclusions from the study.

Diagnostic criteria-All patients in the study had blood and bone 
marrow smears stained by May-Grunwald-Giemsa, Sudan black, periodic-acid Schiff, and either combined esterase or non-specific esterase with and without sodium fluoride. Standard criteria for the diagnosis of acute myelogenous leukaemia were used; all marrows were hypercellular at the time of first treatment and all showed greater than $50 \%$ infiltration with blast cells. A previous bone marrow abnormality did not require exclusion of the patient from the study. For complete

TABLE I-Clinical details of 91 patients with acute myelogenous leukaemia before treatment

\begin{tabular}{lccc}
\hline & Regimen I & Regimen II & Total \\
\hline No of patients & 50 & 41 & 91 \\
Sex (M:F ratio & $24: 26$ & $22: 19$ & $46-45$ \\
Age (years): & $15-76$ & $15-74$ & $15-76$ \\
Range & $46 \cdot 0$ & $50 \cdot 0$ & $49 \cdot 0$ \\
Mean & 46 & 54 & 50 \\
Median & $0.01-392$ & $0 \cdot 01-329$ & $0 \cdot 01-392$ \\
Blast count $\left(\times 10^{\circ} / 1\right):$ & $42 \cdot 3$ & $40 \cdot 1$ & $41 \cdot 0$ \\
Range & $19 \cdot 3$ & $11 \cdot 8$ & $15 \cdot 8$ \\
Mean & $10-199$ & $10-157$ & $10-199$ \\
Median & 77 & 55 & 73 \\
Platelet count $\left(\times 10^{\circ} / 1\right):$ & 63 & 37 & 40 \\
Range & & & \\
Mean & & & \\
Median & & & \\
& & &
\end{tabular}

TABLE II-Morphological variants in 91 patients with acute myelogenous leukaemia in two treatment groups

\begin{tabular}{cccc}
\hline $\begin{array}{c}\text { FAB } \\
\text { classification }\end{array}$ & Regimen I & Regimen II & Total \\
\hline M1 & 15 & 14 & 29 \\
M3 & 11 & 8 & 19 \\
M4 & 2 & 4 & 6 \\
M5 & 14 & 11 & 25 \\
M6 & 5 & 2 & 7 \\
\hline Total & 50 & 41 & 91 \\
\hline
\end{tabular}

TABLE III-Details of two drug regimens for the treatment of acute myelogenous leukaemia

\begin{tabular}{|c|c|c|c|}
\hline Drug & $\begin{array}{l}\text { Dose } \\
\text { (daily) }\end{array}$ & Days & Cycles \\
\hline \multicolumn{4}{|c|}{ Regimen I } \\
\hline Doxorubicin & $\begin{array}{l}50 \mathrm{mg} / \mathrm{m}^{2} \\
50 \mathrm{mg} / \mathrm{m}^{2} \\
25 \mathrm{mg} / \mathrm{m}^{2} \\
50 \mathrm{mg} / \mathrm{m}^{2}\end{array}$ & $\left.\begin{array}{l}1 \\
2 \\
1-2\end{array}\right\}$ & $\begin{array}{l}1-2 \\
3-4 \\
5-6\end{array}$ \\
\hline Cytarabine* & $200 \mathrm{mg} / \mathrm{m}^{2}$ & $1-5$ & $1-6$ \\
\hline 6-Thioguanine & $\begin{array}{c}200 \mathrm{mg} / \mathrm{m}^{2} \\
\text { Regimen II }\end{array}$ & $1-5$ & $1-6$ \\
\hline Doxorubicin & $25 \mathrm{mg} / \mathrm{m}^{2}$ & $1-3$ & $1-6$ \\
\hline Cytarabine* & $\begin{array}{l}200 \mathrm{mg} / \mathrm{m}^{2} \\
200 \mathrm{mg} / \mathrm{m}^{2}\end{array}$ & $\begin{array}{l}1-7 \\
1-5\end{array}$ & $\begin{array}{l}1-2 \\
3-6\end{array}$ \\
\hline 6-Thioguanine & $\begin{array}{l}200 \mathrm{mg} / \mathrm{m}^{2} \\
200 \mathrm{mg} / \mathrm{m}^{2}\end{array}$ & $\begin{array}{l}1-7 \\
1-5\end{array}$ & $\begin{array}{l}1-2 \\
3-6\end{array}$ \\
\hline
\end{tabular}

remission the patient had to be in normal health with a haemoglobin concentration of $>10.0 \mathrm{~g} / \mathrm{dl}$, neutrophils $>1.0 \times 10^{\circ} / 1$, and platelets $>100 \times 10^{9} / 1$. The bone marrow had to be normocellular with representation of all cell lines in normal numbers with less than $5 \%$ blasts (hypoplastic or regenerating marrows were not accepted). Bone marrows were performed during remission when indicated clinically or if cytopenia occurred. Relapse was diagnosed if blast cells in the marrow increased above $5 \%$

Prevention and treatment of infection-Patients were nursed in an open ward with no special precautions other than routine hand washing. Consenting patients were included in a randomised study of prophylactic cotrimoxazole, and in the early part of the study non-absorbable antibiotics were not used. The final 34 patients, all of whom received regimen $\mathrm{I}$, received prophylactic treatment of the bowel with nonabsorbable antibiotics. ${ }^{7} \mathrm{~A}$ fever above $38^{\circ} \mathrm{C}$ twice in four hours was taken as evidence of infection and an indication to begin antibiotic w treatment, usually with an aminoglycoside-cephalosporin combination. $\frac{7}{z}$ Treatment was modified according to clinical circumstances and microbiological results.

Prevention of haemorrhage-Single donor platelets harvested with a Haemonetics model 30 were given when the platelet count was less than $20 \times 10^{9} / 1$ or if clinically indicated. Donor platelets were obtained either from relatives or from the blood transfusion service. If alloimmunisation was present or suspected platelets from related or ${ }^{\mathcal{D}}$ unrelated HLA-matched donors were obtained whenever possible.

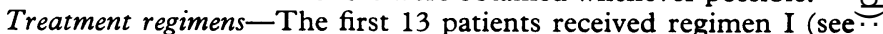
table III). Since the initial post-treatment bone marrow did not show $\overrightarrow{\vec{F}}$ complete aplasia it was decided to increase the intensity of the first two cycles and give the subsequent 41 patients regimen II. An unacceptably high early mortality occurred in these patients and the remaining 37 were consequently treated with regimen $\mathrm{I}$. The aim of both regimens $\frac{\bar{\rho}}{\partial}$ was to prescribe six treatment cycles in as short a time as the patient $\mathbb{D}$ could tolerate. The bone marrow was examined three weeks after the beginning of each cycle until complete remission occurred. If the ${ }^{\infty}$ bone marrow was hypercellular and showed persistent leukaemia the $\vec{O}$ next cycle was begun without delay, provided the patient was clinically fit enough. If the bone marrow was normocellular or hypocellular and $\vec{\omega}$ confirmed that the proportion of leukaemic cells was reduced, treatment was withheld until the peripheral blood count recovered or $\underline{\underline{ }}$ subsequent bone marrow examination showed repopulation with blast cells. The mean time between cycles was 26 days with both regimens.

Bone marrow transplantation-Where the treatment regimen was completed patients under 40 years with HLA-identical siblingsw received ablative chemoradiotherapy supported by allogeneic bonef marrow transplantation in a combined study at the Royal Marsden $\overrightarrow{\mathrm{N}}$ Hospital (Dr R L Powles)

Statistical analysis-Survival and remission duration curves were $\overrightarrow{0}$ analysed by standard life tables ${ }^{8}$ and tests of significance by the log rank method. ${ }^{9}$ Remission proportions were compared by the $\chi^{2} N$ test with Yates's correction. ${ }^{8}$

\section{Results}

Response to initial treatment-Complete remission was achieved in $49 / 91(51 \%)$ patients. The complete remission rate was significantly higher $(p<0.01)$ for patients receiving regimen $I(34 / 50)$ than for those receiving regimen II (15/41), and this was independent of all the other variables analysed (table IV). The reasons for failure to achieve complete remission are shown in table V; a much higher rate of fatale infection occurred in patients receiving regimen II $(13 / 41 v 5 / 50)$. $\overrightarrow{\vec{O}}$ The duration of profound neutropenia was the same with both regimens, the neutrophil count remaining below $0.5 \times 10^{\circ} / 1$ for a mean of 27 days with regimen I and of 29 days with regimen II in the firsto and second cycles. Complete remission was achieved after 1-6 cycles (median 3 for regimen I and 4 for regimen II). Both medians may be artificially high because of the policy of proceeding with treatment $<$ rather than waiting for complete recovery of the bone marrow too

TABLE IV-Correlation between presentation features and response to treatment

\begin{tabular}{|c|c|c|c|c|c|c|c|}
\hline & \multicolumn{2}{|c|}{ Regimen I } & \multicolumn{2}{|c|}{ Regimen II } & \multicolumn{2}{|c|}{ Total } & N \\
\hline & No & $\%$ & No & $\%$ & No & $\%$ & $D$ \\
\hline Patients & $34 / 50$ & 68 & $15 / 41$ & 37 & $49 / 91$ & 51 & 晋. \\
\hline $\begin{array}{l}<60 \\
>60 \\
\text { Sex: }\end{array}$ & $\begin{array}{r}29 / 36 \\
5 / 14\end{array}$ & $\begin{array}{l}80 \\
36\end{array}$ & $\begin{array}{r}11 / 27 \\
4 / 14\end{array}$ & $\begin{array}{l}40 \\
29\end{array}$ & $\begin{array}{r}40 / 63 \\
9 / 28\end{array}$ & $\begin{array}{l}63 \\
32\end{array}$ & స్ \\
\hline Male & $\begin{array}{l}18 / 24 \\
16 / 26\end{array}$ & $\begin{array}{l}75 \\
62\end{array}$ & $\begin{array}{r}10 / 22 \\
5 / 19\end{array}$ & $\begin{array}{l}45 \\
26\end{array}$ & $\begin{array}{l}28 / 46 \\
21 / 45\end{array}$ & $\begin{array}{l}61 \\
47\end{array}$ & $\underset{<}{\sigma}$ \\
\hline $\begin{array}{l}\text { Blast count }\left(\times 10^{9} / 1\right) \text { : } \\
0-10 \\
11-100 \\
>100\end{array}$ & $\begin{array}{c}18 / 23 \\
14 / 21 \\
2 / 6\end{array}$ & $\begin{array}{l}78 \\
66 \\
33\end{array}$ & $\begin{array}{l}7 / 20 \\
8 / 14 \\
0 / 7\end{array}$ & $\begin{array}{r}35 \\
57 \\
0\end{array}$ & $\begin{array}{r}25 / 43 \\
22 / 35 \\
2 / 13\end{array}$ & $\begin{array}{l}58 \\
63 \\
15\end{array}$ & 邑 \\
\hline $\begin{array}{l}\text { Neutrophil count: } \\
<10^{\circ} / 1 \\
>10^{\circ} / 1\end{array}$ & $\begin{array}{c}2 / 6 \\
16 / 27 \\
18 / 23\end{array}$ & $\begin{array}{l}33 \\
59 \\
78\end{array}$ & $\begin{array}{l}0 / 7 \\
8 / 20 \\
7 / 21\end{array}$ & $\begin{array}{r}0 \\
40 \\
33\end{array}$ & $\begin{array}{r}2 / 13 \\
24 / 47 \\
25 / 44\end{array}$ & $\begin{array}{l}15 \\
51 \\
57\end{array}$ & 뭄 \\
\hline $\begin{array}{l}\text { Platelet count }\left(\times 10^{\circ} / 1\right) \text { : } \\
\quad<20 \\
>20 \\
\text { Liver and spleen }\end{array}$ & $\begin{array}{c}6 / 6 \\
28 / 44\end{array}$ & $\begin{array}{r}100 \\
64\end{array}$ & $\begin{array}{l}1 / 9 \\
14 / 32\end{array}$ & $\begin{array}{l}11 \\
44\end{array}$ & $\begin{array}{r}7 / 15 \\
42 / 76\end{array}$ & $\begin{array}{l}47 \\
55\end{array}$ & 蛋 \\
\hline $\begin{array}{l}\text { enlargement: } \\
\text { Hepatosplenomegaly } \\
\text { Hepatomegaly only } \\
\text { Splenomegaly only } \\
\text { Neither } \\
\text { Lymph node }\end{array}$ & $\begin{array}{l}9 / 12 \\
6 / 12 \\
2 / 5 \\
17 / 21\end{array}$ & $\begin{array}{l}75 \\
50 \\
40 \\
81\end{array}$ & $\begin{array}{c}1 / 7 \\
1 / 5 \\
3 / 5 \\
10 / 24\end{array}$ & $\begin{array}{l}14 \\
20 \\
60 \\
42\end{array}$ & $\begin{array}{r}10 / 19 \\
7 / 17 \\
5 / 10 \\
27 / 45\end{array}$ & $\begin{array}{l}53 \\
41 \\
50 \\
60\end{array}$ & $\begin{array}{l}\text { ర్ } \\
\text { 음 }\end{array}$ \\
\hline $\begin{array}{l}\text { enlargement: } \\
\text { Present } \\
\text { Absent }\end{array}$ & $\begin{array}{l}15 / 24 \\
19 / 26\end{array}$ & $\begin{array}{l}63 \\
73\end{array}$ & $\begin{array}{l}6 / 13 \\
9 / 28\end{array}$ & $\begin{array}{l}46 \\
32\end{array}$ & $\begin{array}{l}21 / 37 \\
28 / 54\end{array}$ & $\begin{array}{l}57 \\
51\end{array}$ & 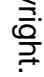 \\
\hline
\end{tabular}


confirm complete remission. The complete remission rate correlated significantly with the blast cell count at presentation $(p<0.01)$; patients with a lower blast cell count had a greater probability of entering complete remission. Younger patients were also more likely to enter complete remission. None of the other factors analysed, including the morphological subtype (table II), correlated with the response to initial treatment.

TABLE v-Analysis of treatment failures. (Number of patients in two treatment groups)

\begin{tabular}{lccc}
\hline & Regimen I & Regimen II & Total \\
\hline Resistant leukaemia & 8 & 6 & 14 \\
Fatal infection & 5 & 13 & 18 \\
Haemorrhagic death & 2 & 3 & 5 \\
Other & 1 & 4 & 5 \\
\hline Total & 16 & 26 & 42 \\
\hline
\end{tabular}

Duration of first remission-Twenty-one patients remain in continuous complete remission between 17 months and 37 months (fig 1). Four of these received HLA-identical bone marrow grafts at seven, 18, 19, and 20 weeks. All are still in remission but have been excluded from all analyses since transplantation. Two other patients died in complete remission, one of Gram-negative septicaemia and one of myocardial infarction at three weeks and six months respectively. The median duration of first complete remission was one year. Prolonged remission was significantly more likely for patients receiving more intensive (regimen II) than less intensive initial treatment ( $p$ $<0.05)$ in contrast with the likelihood of achieving complete remission. Eight out of 13 patients receiving regimen II who entered remission but did not undergo transplantation are still without relapse between two and three years (the median not yet having been reached) compared with $9 / 32$ receiving regimen I (median eight months).

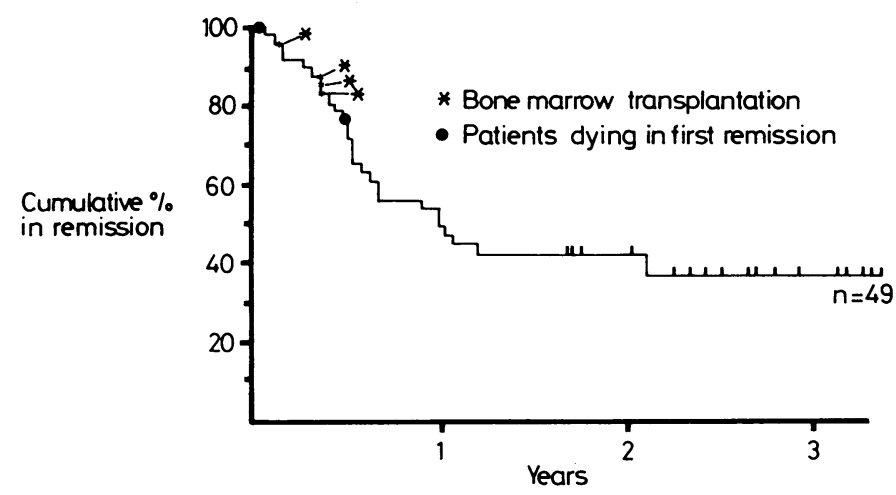

FIG 1-Duration of first remission in patients with acute myelogenous leukaemia (regimen I and regimen II).

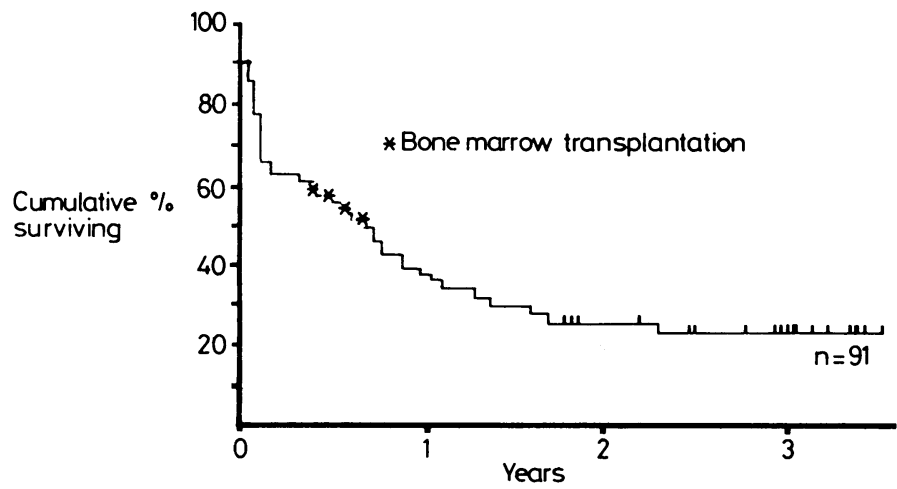

FIG 2-Overall survival in acute myelogenous leukaemia (comparison with earlier trials at St Bartholomew's Hospital).

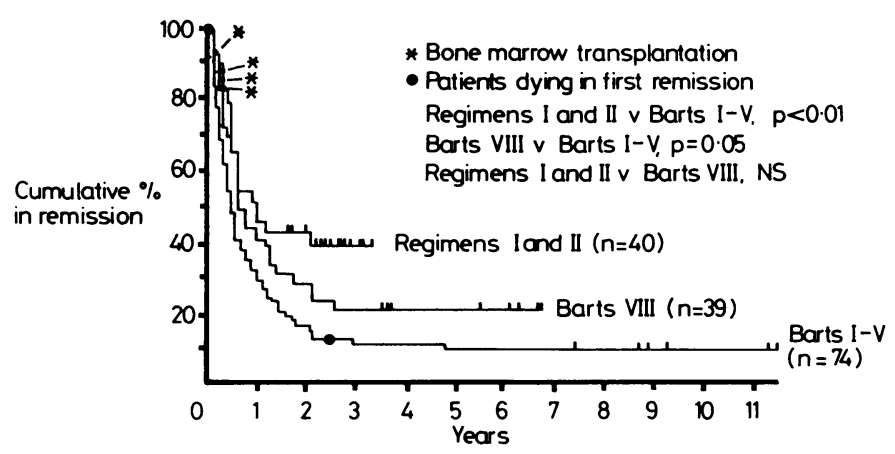

FIG 3-Duration of first remission in acute myelogenous leukaemia (comparison with earlier trials at St Bartholomew's Hospital).

Survival-Twenty-three out of 91 patients are still alive (fig 2). Two patients who received regimen I died in complete remission, one, aged 60 , of Gram-negative septicaemia during consolidation, while profoundly neutropenic, the other, aged 70, of a myocardial infarction after having received only $125 \mathrm{mg}$ doxorubicin $/ \mathrm{m}^{2}$. Response to initial treatment correlated very closely with survival; patients in whom complete remission was achieved had a significantly greater probability of long-term survival than those in whom it was not $(p<0.01)$.

\section{Discussion}

The objectives of this study were to improve the proportion of patients entering complete remission, thereby increasing the proportion of patients "at risk for cure"; and to establish whether very intensive short-term chemotherapy could result in remissions as long as those achieved in other recent studies, thus making it an acceptable strategy for the treatment of acute myelogenous leukaemia. Both of these objectives depended on the intensity of the initial treatment. A significant improvement in the complete remission rate was achieved with regimen I though not with regimen II; in fact, among patients under the age of 60 receiving regimen $I$ it was significantly better than that previously achieved at St Bartholomew's Hospital and compared favourably with results achieved elsewhere. ${ }^{5610-15}$

Since the maximum follow-up period has been only three years, it is not yet possible to comment on the duration of remission or overall survival. Nevertheless, there is no evidence at all from the shape of the curves so far that a policy of short-term treatment has compromised the prognosis of this group of patients. On the contrary, although not statistically significant, the duration of remission of the whole group of patients under the age of 60 appears to be longer than previously achieved, with a significant advantage for those patients receiving the more intensive regimen (fig 3 ). Whether or not the greater intensity of regimen II was responsible for a higher proportion of patients in this group being "at risk for cure," as previously hypothesised, ${ }^{16}$ remains to be established in larger studies. Probably the gradual increase in the intensity of remission induction and consolidation treatment for acute myelogenous leukaemia made prolonged maintenance therapy superfluous for most patients. We are encouraged by our results to investigate short-term chemotherapy complemented by bone marrow transplantation when possible. Rather than continue with the less intensive of the two regimens, we consider it more appropriate to improve the supportive care of the patients during the first month of treatment and so allow the early treatment to be intensified further. This appears to be the only way presently available of increasing the proportion of patients cured. ${ }^{17} 18$

We thank the nursing and medical staff of Dalziel and Annie Zunz wards for their expert care and acknowledge the contribution of the medical and technical staff of the department of haematology and the help of the technical and biostatistical staff of the department of medical oncology. We are also grateful for the secretarial help. The manuscript was typed first by Jill and then by Sara. 


\section{References}

1 Crowther D, Powles RL, Bateman CJT, et al. Management of adult acute myelogenous leukaemia. $\mathrm{Br}$ Med f $1973 ; \mathrm{i}: 131-7$.

2 Powles RL, Russell J, Lister TA, et al. Immunotherapy for acute myelogenous leukaemia. A controlled clinical study $2 \frac{1}{2}$ years after entry of last patient. Br $\mathcal{F}$ Cancer $1977 ; 35: 265-75$.

${ }^{3}$ Lister TA, Johnson SAN, Bell R, Henry G, Malpas JS. Progress in acute myelogenous leukaemia. In: Neth R, Gallo RC, Graf T, Mannweiler K, Winkler $\mathrm{K}$, eds. Modern trends in human leukaemia. IV. Berlin: Springer-Verlag, $1981: 38$

4 Lister TA, Whitehouse JMA, Oliver RTD, et al. Chemotherapy and immunotherapy for acute myelogenous leukaemia. Cancer $1980 ; 46: 2142-8$.

${ }^{5}$ Rees JKH, Sandler RM, Callener J, Hayhoe FGJ. Treatment of acute myeloid leukaemia with a triple cytotoxic regimen: DAT. Br $\mathcal{F}$ Cancer $1977 ; 36: 770-4$.

${ }^{6}$ Gale RP, Cline MJ. High remission induction rate in acute myeloid leukaemia. Lancet $1977 ; \mathrm{i}: 497-9$.

${ }^{7}$ Schimpff SC, Grene WH, Young VM, Fratner CC, Jepson J, Cusack N. Infection prevention in acute non-lymphocytic leukaemia. Laminar air flow room reverse isolation with oral non-absorbable antibiotic prophylaxis. Ann Intern Med 1975;36:770-4.

${ }^{8}$ Armitage P. Statistical methods in medical research. London: Halstead Press, 1971.

- Peto R, Pike MC, Armitage P, et al. Design and analysis of randomised clinical trials requiring prolonged observation of each patient. II Analysis and examples. Br $\mathcal{F}$ Cancer 1977;35:1-39.

10 Preisler HD, Bhornsson S, Henderson ES. Adriamycin cytosine arabino- side therapy for acute myelocytic leukaemia. Cancer Treat Rep 1977; $61: 89-92$.

11 McCredie KB, Bodey GP, Freireich EJ, Hester JP, Rodriguez V, Keating MJ. Chemoimmunotherapy for adult acute leukaemia. Cancer 1981; 47:1256-61.

12 Smith W, Applebaum F, Fefer A, Glucksberg H, Cheaver N, Thomas ED. Intensive therapy of adult acute nonlymphoblastic leukaemia (ANL). Proceedings of the American Society of Clinical Oncology 1980;21:455.

13 Weinstein HJ, Mayer RJ, Rosenthal DS, et al. Treatment of acute myelogenous leukaemia in children and adults. $N$ Engl $F$ Med $1980 ; 303: 473-8$.

14 Arlin Z, Gee T, Frid J, Roenigsberg E, Wamark N, Clarkson B. Rapid induction of remission in acute non-lymphocytic leukaemia (ANLL) Proceedings of the American Association for Cancer Research 1979;20:112.

15 Glucksberg H, Cheever MA, Farewell VT, Fefer A, Sale GE, Thomas ED. High dose combination chemotherapy for acute nonlymphocytic leukaemia in adults. Cancer 1981;48:1073-81.

16 Jackson RRP, Birkhead BG, Bell R, Lister TA, Gregory WH. Application of Jackson-Aspden acute myeloid leukaemia model. Fournal of the Operational Research Society (in press).

${ }^{17}$ Mayer RJ, Coral FS, Rosenthal DS. The role of intensive post induction chemotherapy on the management of patients with acute myelogenous leukaemia. Cancer Treat Rep (in press).

18 Preisler HD, Brecher M, Browman G, et al. The treatment of acute myelogenous leukaemia in children and young adults. (Submitted for publication.)

\title{
Malalignment of the shoulder after stroke
}

\author{
R G SMITH，J G CRUIKSHANK，SHELAGH DUNBAR， A J AKHTAR
}

\begin{abstract}
One hundred and ten consecutive patients (51 men, 59 women) admitted to a stroke unit were studied for radiographic changes at the shoulder on the affected side. Malalignment was found in $51(46 \%)$ patients, of whom $37(72.5 \%)$ had changes on the initial $x$-ray film and a further $14(27 \cdot 5 \%)$ developed malalignment over the following 12 months. These findings indicate that malalignment of the shoulder is common in the early stages of a stroke and may be missed unless radiographs are taken with the patient erect and the arm unsupported. Malalignment may lead to delay and limitation in restoration of function. The consequences of malalignment can be prevented by correct handling, positioning, and full passive movement of the shoulder from the onset of the stroke.
\end{abstract}

\section{Introduction}

Several studies ${ }^{1-6}$ have shown that the prevalence of subluxation of the affected shoulder after a stroke is between $17 \%$ and $60 \%$. No changes have been reported in non-hemiplegic controls. ${ }^{3}$ Since all of these studies have been retrospective, we do not know whether the changes of subluxation take place

\footnotetext{
University Department of Geriatric Medicine, City Hospital, Edinburgh EH10 5SB

R G SMITH, FRCPE, senior lecturer
}

\section{Royal Victoria Hospital, Edinburgh EH4 2DN}

J G CRUIKSHANK, FRCPE, FRCR, consultant radiologist

SHELAGH DUNBAR, MCSP, physiotherapist

A J AKHTAR, FRCPE, consultant physician in geriatric medicine soon after the stroke or as a later result of paralysis and disuse. To determine the incidence and time of occurrence of subluxation, we decided to examine prospectively patients with acute stroke for malalignment of the shoulder and record the progression of the condition and its association with the degree of paralysis.

\section{Patients and methods}

A prospective study of 110 consecutive admissions to the stroke unit at the Royal Victoria Hospital, Edinburgh, was planned with the aim of following up each patient for one year. The criteria for admission to the stroke unit have been described. ${ }^{7}$ The patients were examined within 24 hours of admission and the following information collected: date of onset of stroke; date of admission to the stroke unit; affected side of body; grade of power in affected upper limb at the elbow (using the Medical Research Council scale $0-5$ ); and the relevant history, especially of a previous stroke.

If the patient's condition permitted, radiographs of both shoulders were taken with the patient both supine and erect with the arm unsupported. Radiographic examination was repeated at one, two, three, six, and 12 months. The date of death was recorded if it occurred during the 12 months. At the end of the study all the radiographs were examined and abnormalities noted. The two independent examiners (RGS and JGC) had no difficulty in interpreting the grades of malalignment.

The 110 patients comprised 51 men and 59 women with a mean age of 72.6 years (range 59-93) for men and 75.3 years (range 61-93) for women (table I). Seventy-nine patients were admitted within 48 hours of the onset of the stroke, 51 on the same day. Two patients were not admitted until more than 14 days after the stroke. In 59 patients the left arm was affected and in 51 the right. Various degrees of paralysis of the affected upper limb were found. Forty-one of the 110 patients died within a year of their stroke, 21 within the first month. Ten patients were lost to follow-up as they left the Edinburgh area, and 27 were discharged from follow-up before 12 months as they had made a satisfactory recovery. Thirty-two patients were followed to the end of the study. 